\title{
Histological analysis of the eyeball of Neotropical birds of prey Caracara plancus, Falco sparverius, Rupornis magnirostris, Megascops choliba and Athene cunicularia
}

\author{
Análise histológica do bulbo ocular de aves de rapina neotropicais: Caracara plancus, Falco \\ sparverius, Rupornis magnirostris, Megascops choliba e Athene cunicularia
}

\author{
Débora Galdino PINTO' ${ }^{1}$; Guilherme Durante $\mathrm{CRUZ}^{2}$; Rodrigo Hidalgo Friciello TEIXEIRA ${ }^{3}$; Erica Pereira \\ COUTO $^{4}$; Marcelo Pires Nogueira de CARVALHO ${ }^{1}$ \\ ${ }^{1}$ Universidade de São Paulo, Faculdade de Medicina Veterinária e Zootecnia, São Paulo - SP, Brazil \\ ${ }^{2}$ Universidade de Santo Amaro, São Paulo - SP, Brazil \\ ${ }^{3}$ Parque Zoológico Municipal Quinzinho de Barros, Sorocaba - SP, Brazil \\ ${ }^{4}$ Tukan - Consultório de Animais Silvestres, São Paulo - SP, Brazil
}

\begin{abstract}
The growing use of ophthalmic examination as a screening tool in birds intended for reintroduction into natural environments over the last few years has given renewed significance to avian ophthalmology in the context of free-ranging and captive bird conservation. The eye plays a vital role in prey detection and capture by birds of prey. The remarkable eyesight of such birds makes them interesting subjects for avian visual system anatomical and histological investigation. This study set out to describe histological features of the eyeball of ubiquitous birds of prey in Brazil (Falconiformes, Accipitriformes and Strigiformes). Twenty enucleated cadaveric eyeballs obtained from birds with natural death, Caracara plancus, Falco sparverius, Rupornis magnirostris, Megascops choliba and Athene cunicularia were used. Routinely prepared histological slides stained with hematoxylin and eosin were analyzed under light microscopy. Similarities and variations in ocular structures between the different bird species studied were highlighted in this study, with major differences concerning the lens and retina. This study highlights the importance of determining the ocular histological pattern of the species so they can be better understood. These results may well assign baseline information of the species and assist in eye histopathological diagnostics.
\end{abstract}

Keywords: Birds. Eyeball. Histology.

\section{Resumo}

Nos últimos anos a oftalmologia aviária se tornou um instrumento de grande relevância para a conservação de aves de vida livre e de cativeiro, principalmente pela crescente utilização do exame oftalmológico para a triagem de indivíduos designados para reintrodução em ambientes naturais. Os olhos das aves de rapina são estruturas imprescindíveis para detectar e capturar suas presas, e a sua notável capacidade visual torna o seu sistema de visão assunto de grande interesse para o estudo anatômico e histológico. Neste contexto, no presente trabalho foi realizada a análise histológica do bulbo ocular de aves de rapina representadas por espécies pertencentes às ordens Falconiformes, Accipitriformes e Strigiformes presentes em território brasileiro. Para realização do estudo foram utilizados vinte bulbos oculares obtidos de animais mortos por causas naturais, das espécies Caracara plancus, Falco sparverius, Rupornis magnirostris, Megascops choliba e Athene cunicularia.. As lâminas histológicas foram coradas pela técnica de hematoxilina e eosina e, analisadas por microscopia óptica. Foi constatada a existência de um padrão histológico com discreta variação entre as estruturas oculares nas diferentes espécies avaliadas, com destaque para o cristalino e a retina. Este estudo salienta a importância da determinação do padrão histológico ocular das espécies, e seus resultados atribuem informações histológicas basais auxiliares na determinação de diagnósticos histopatológicos oculares.

Palavras-chave: Aves. Bulbo ocular. Histologia. 
Correspondence to:

Débora Galdino Pinto

Universidade de São Paulo, Faculdade de Medicina

Veterinária e Zootecnia

Av. Prof. Dr. Orlando Marques de Paiva, 87

CEP 05508-270, São Paulo, SP, Brazil

e-mail: deboragaldino@usp.br

Received: 29/12/2015

Approved: 15/08/2016

\section{Introduction}

The increasing use of ophthalmic examination as a screening tool in birds intended for reintroduction into natural environments over the last few years has highlighted the significance of avian ophthalmology in conservation of free-ranging and captive birds of prey. These kind of birds are carnivorous predators with diurnal or nocturnal habits of the orders Accipitriformes (eagles and hawks), Falconiformes (falcons) and Strigiformes (owls). (SICK, 1997). Their eyes play a vital role in prey detection and capture by birds of prey (ZUCCA, 2002). Frontally positioned eyes provide these birds with binocular vision and represent an adaptation to hunting (SOARES et al., 2008). Their visual acuity and complex retinal structures (PINTO et al., 2011) render them particularly interesting for anatomical and histological study of the avian visual system.

This study set out to describe histological features of the eye in birds of prey belonging to the orders Falconiformes, Accipitriformes and Strigiformes, ubiquitous in Brazil. It is hoped that the data presented here will contribute to the understanding of the subject of avian ophthalmology and help improve ophthalmic care provided to wild birds.

\section{Material and Methods}

Twenty enucleated cadaveric eyeballs were used in this study. Eyeballs were obtained from birds that died from natural causes, as follows: Athene cunicularia (three), Cararaca plancus (one), Falco sparverius (one), Megascops choliba (two) and Rupornis magnirostris (three). The eyeballs from cadaver birds were donated by Parque Zoológico Municipal Quinzinho de Barros, Sorocaba - SP.

Eyeballs were enucleated performing circular periorbital incisions with scalpel and scissors, and immediately fixed in $10 \%$ formalin. Anatomical specimens were cut and processed according to routine paraffin embedding method; $5 \mu \mathrm{m}$ slices were then obtained using a rotating micrometer, mounted onto glass slides and stained with hematoxylin and eosin. Histological analyses were performed under light microscopy using a binocular Nikon E200 microscope.

Histological features were photographically documented using Go-5 Datasheet-QImaging camera adapted to an Olympus BX50 optical microscope. Image-Pro 3DS ${ }^{\circ}$ was used for image capture.

\section{Results}

Histological analysis of the cornea of the species studied (Caracara plancus, Falco sparverius, Rupornis magnirostris, Megascops choliba and Athene cunicularia) revealed an avascular tissue composed by anterior epithelium, Bowman's membrane, stroma, Descemet's membrane and posterior epithelium (Figure 1A). The anterior epithelium consisted of stratified, non-keratinized epithelium comprising four to five (Caracara plancus and Falco sparverius) (Figure 1B), three (Rupornis magnirostris) (Figure 1C) or two (Megascops choliba and Athene cunicularia) cell layers (Figure 1D).

The sclera had similar structure in all species studied, corresponding to dense connective tissue and hyaline cartilage. The hyaline cartilage extended all the way to the sclerotic ring formed by marrow-filled scleral ossicles (Figure 1E).

In all of the birds studied, the iris consisted of a vascular stroma and constrictor and dilator muscle fibers; irregular (i.e., with outgrowths), pigmented posterior epithelium continuing with the ciliary body was documented. The ciliary body, divided into pars plana and pars plicata, was continuous with the posterior epithelium of the iris and the anterior epithelium of the choroid. The pars plicata (Figure 1F) 


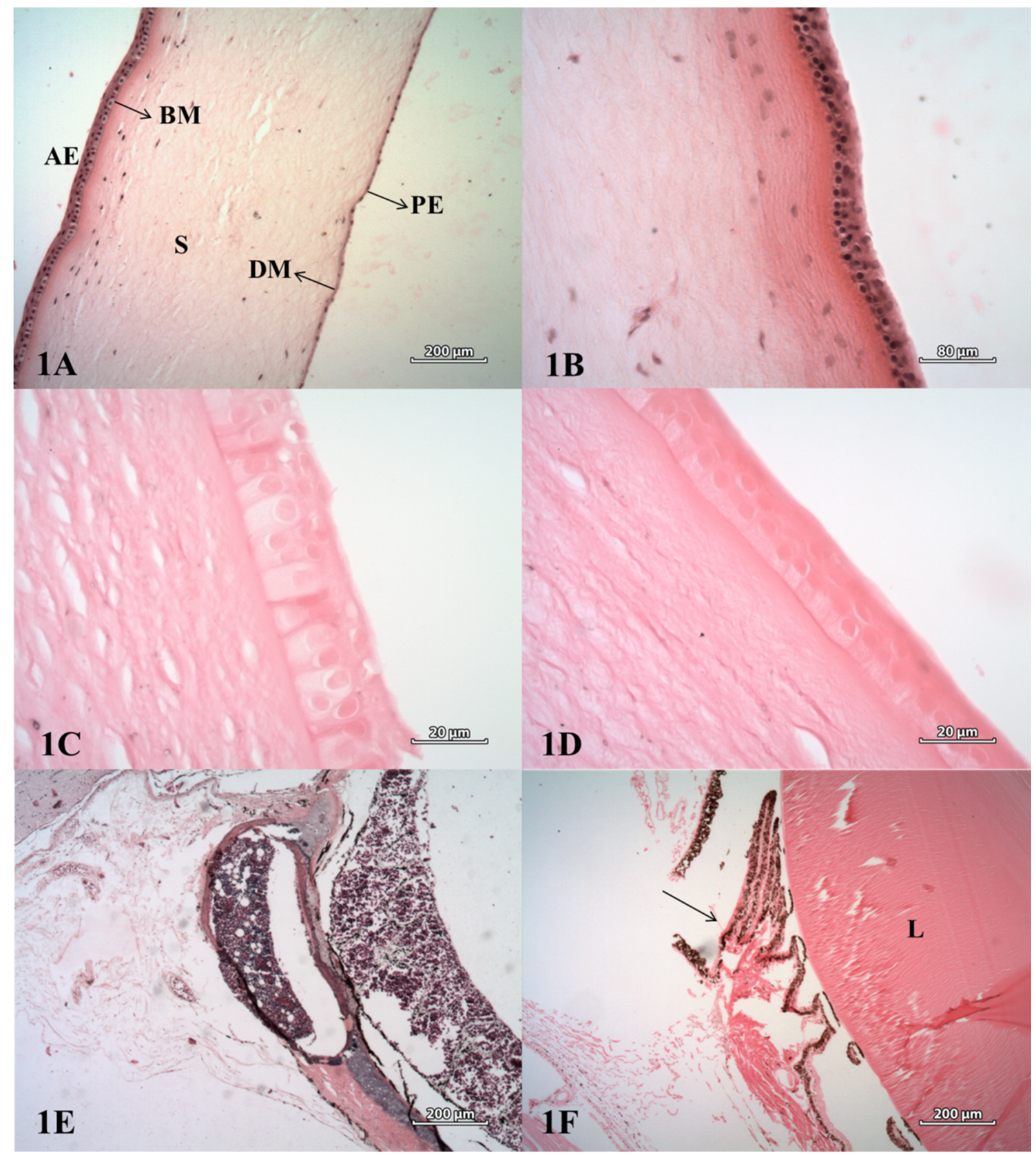

Figure 1 - A) Cornea (Falco sparverius): Avascular tissue comprising anterior epithelium (AE), Bowman's membrane (BM), stroma (S), Descemet's membrane (DM) and posterior epithelium (PE). Method HE staining; B) Cornea: Anterior epithelium comprising four cell layers in Falco sparverius Method HE staining; C) Cornea: Anterior epithelium comprising three cell layers in Rupornis magnirostris. Method HE staining; D) Cornea: Anterior epithelium comprising two cell layers in Megascops choliba. Method HE staining; E) Cartilage and bone of the sclerotic ring ossicle (Falco sparverius). Method HE staining; $\underline{\text { F }}$ Ciliary body (pars plicata) (arrow) and lens (L) (Athene cunicularia). Method HE staining

was formed by ciliary processes, where zonular fibers involved in lens accommodation arise.

The lens of all of the birds was surrounded by a capsule laid over oblique and horizontal lenticular fibers in all birds studied. Different from the other species in the sample, longer superficial epithelial cells with broader, more eosinophilic cytoplasm and nuclei were observed under the capsule in Athene cunicularia (Figure 2A).

In the specimens studied, the choroid comprised a more external pigmented layer adhered to the sclera (suprachoroid) and a more internal, highly vascular layer (Figure 2B) involved in anangiotic retina nutrition. 
The retinal pigment epithelium was found to be more heavily pigmented in Caracara plancus, Falco sparverius and Rupornis magnirostris (Figure 2C) and less developed and pigmented in Megascops choliba (Figure 2D) compared to Athene cunicularia (Figure
2E).

The pecten oculi (Figure 2F) in all sampled birds presented a wavy, vascular structure arising from the optic nerve area and projecting into the vitreous chamber.

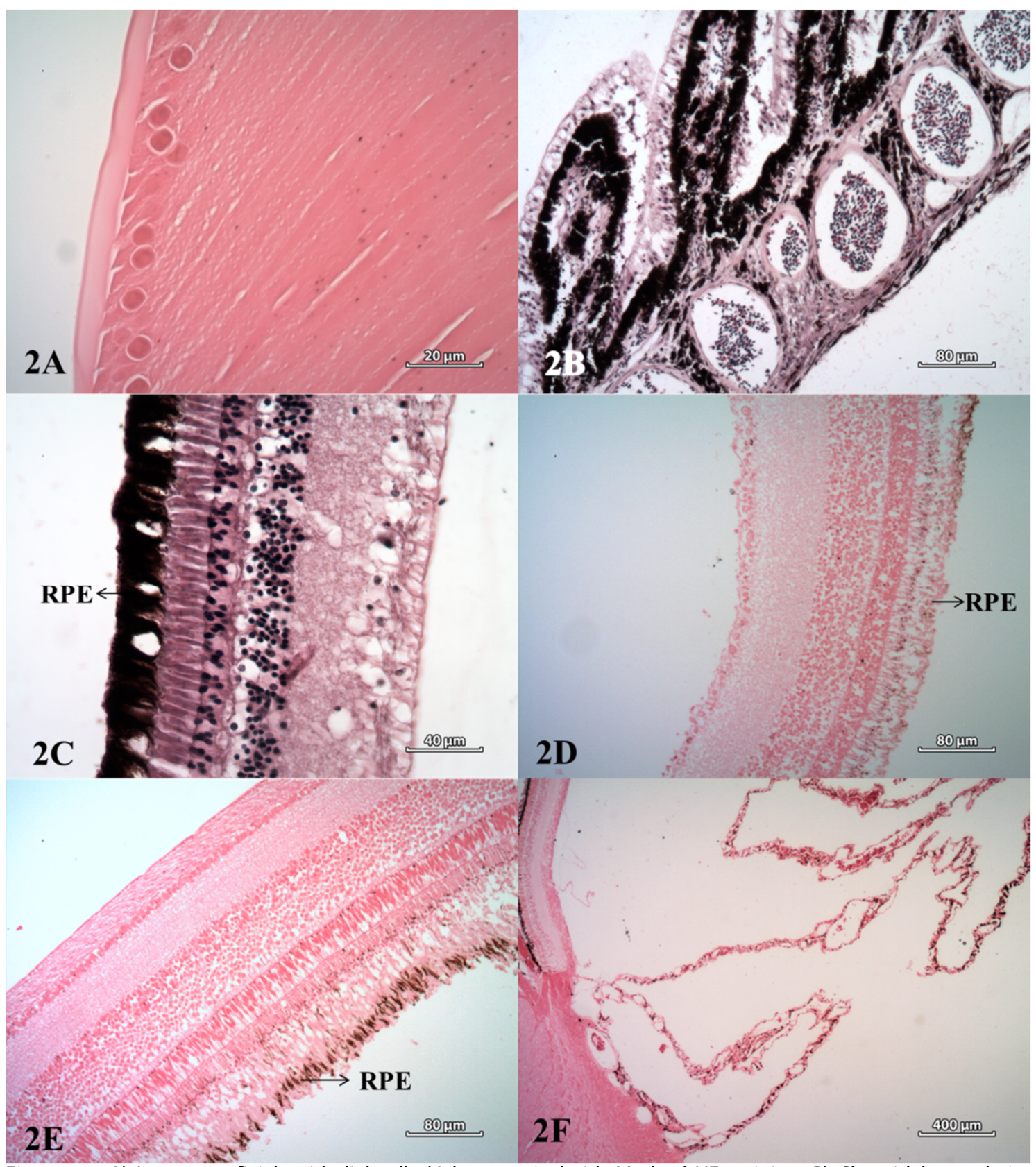

Figure 2 - $\underline{\mathrm{A}}$ ) Lens superficial epithelial cells (Athene cunicularia). Method HE staining; $\underline{B}$ ) Choroidal vascularity (Caracara plancus) with large vessels and hematopoietic cells in the lumen. Method HE staining; $\underline{\mathrm{C}}$ Intense pigmentation in the retinal pigment epithelium (RPE) in Caracara plancus. Method HE staining; D) Retinal pigment epithelium (RPE) with discreet pigmentation in Megascops choliba. Method HE staining; E) Retinal pigment epithelium (RPE) with moderate pigmentation in Athene cunicularia when compared with Caracara plancus and Megascops choliba. Method HE staining; F) Vascularized structure, Pecten oculi, arising from the optic nerve area immersed into vitreous chamber in Rupornis magnirostris. Method HE staining 


\section{Discussion}

Histological analysis of the studied species suggested similarities with other vertebrates (SAMUELSON, 1999), but there are particular species as shown in our results. The avian cornea is known to be considerably thinner than that of other animal species (PISA, 2011), with highly variable thickness within the class (BAYÓN et al., 2007). The Bowman's layer in birds is acellular and differs from that found in humans and primates (STEPP, 2006).

The sclera structure composed of dense connective tissue, hyaline cartilage and ossicles observed in all of the species studied highlights the important in birds of prey to prevent eyeball deformation under the high pressures generated during high speed flight (MAHECHA; OLIVEIRA, 1998).

The choroid and retina structures have the same layers presented by other vertebrates, but the choroid vessels are essential to retina nutrition once the retina is not vascularized.

The variation in the intensity of pigmentation of the retinal pigment epithelium found in the specimens studied may be related to the habit of each species, since the diurnal birds analyzed (Caracara plancus, Falco sparverius and Rupornis magnirostris) presented a more heavily pigmented retinal epithelium when compared with the diurnal species studied.

The pigment melanin present in pigment epithelium offers direct protection against UV radiation damage and is produced by melanocytes (LIN; FISHER, 2007). Melanocyte counts vary in esponse to environmental factors such as sunlight

\section{References}

BAYÓN, A.; ALMELA, R. M.; TALAVERA, J. Avian ophthalmology. European Journal of Companion Animal Practice, v. 17, n. 3, p. 253-266, 2007.

DAYAN, M. O.; OZAYDIN, T. A comparative morphometrical study of the Pecten oculi in differente avian species. The Scientific World Journal, v. 2013, p. 1-5, 2013. doi: $10.1155 / 2013 / 968652$. exposure (MIOT et al., 2009). Diurnal birds are highly exposed to direct sunlight and therefore have higher melanin levels in the retinal pigment epithelium (REDIG; MARTINEZ, 2010).

The vascular structure of pecten oculi observed in all studied species matches with its functions already reported by other authors. Its vascular structure seems to be the responsible for vitreous and retina nutrition and oxygenation in birds (PETTIGREW et al., 1990; DAYAN; OZAYDIN, 2013).

\section{Conclusion}

The present work describes the presence of structural and morphological differences concerning the corneal epithelium of the studied species, in which were found the presence of five to three cell layers in Falconiformes and Accipitriformes and only two layers in Strigiformes. Concerning the retinal pigment epithelium, it was found to be more heavily pigmented in Falconiformes and Accipitriformes and less developed and pigmented in Megascops choliba compared to Athene cunicularia.

Similarities and variations in ocular structures between diurnal and nocturnal bird species studied were highlighted with major differences concerning the cornea and retina structures. This study highlights the importance of determining the ocular histological pattern of the species so they can be better understood and evaluated. These results may well assign baseline information of the species, assist in eye histopathological diagnostics.

LIN, J. Y.; FISHER, D. E. Melanocyte biology and skin pigmentation. Nature, v. 445 , p. $843-850,2007$. doi: $10.1038 /$ nature05660.

MAHECHA, G. A. B.; OLIVEIRA, C. A. An additional bone in the sclera of the eyes of owls and the Common Potoo (Nictibius griseus) and its role in the contraction of the nictitating membrane. Acta Anatomica, v. 163, n. 4, p. 201-211, 1998. doi: 10.1159/000046499. 
MIOT, L. D. B.; MIOT, H. A.; SILVA, M. G.; MARQUES, M. E. A. Fisiopatologia do melasma. Anais Brasileiro de Dermatologia, v. 84, n. 6 , p. $623-635,2009$. doi: 10.1038/nature05660.

PETTIGREW, J. D.; WALLMAN, J.; WILDSOET, C. F. Saccadic oscillations facilitate ocular perfusion from the avian pectin. Nature, v. 343, p. 362-363, 1990. doi: 10.1038/343362a0.

PINTO, D. G.; CRUZ, G. D.; TEIXEIRA, R. H. F. Análise histológica descritiva do globo ocular de Caracara plancus e Falco sparverius (Falconiformes). In: CONGRESSO DA ASSOCIAÇÃO BRASILEIRA DE VETERINÁRIOS DE ANIMAIS SELVAGENS, 14., 2011, Campinas. Anais... Campinas: Abravas, 2011.p. 112-114.

PISA, A. R. C. Tonometria em aves de rapina: aspectos de sua aplicação nas práticas clínicas. 2011. 79 f. Dissertação (Mestrado) - Faculdade de Medicina Veterinária, Universidade Técnica de Lisboa, Lisboa, 2011.

REDIG, P. T.; MARTINEZ, L. C. Rapinantes. In: TULLY, T. N.; DORRESTEIN, G. M.; JONES, A. Clínica de aves. 2. ed. Rio de
Janeiro: Elsevier, 2010. p. 212-213.

SAMUELSON, D. Ophthalmic anatomy. In: GELATT, K. N. Ed. Veterinary ophthalmology. 3. ed. Baltimore: Lippincott Williams \& Wilkins, 1999. p. 31-150.

SICK, H. Ornitologia brasileira. Rio de Janeiro: Nova Fronteira, 1997.912 p.

SOARES, E. S.; AMARAL, F. S. R.; CARVALHO FILHO, E. P. M.; GRANZINOLLI, M. A.; ALBUQUERQUE, J. L. B.; LISBOA, J. S.; AZEVEDO, M. A. G.; MORAES, W.; SANAIOTTI, T.; GUIMARÃES, I. G. Plano de ação nacional para conservação de aves de rapina. Brasília: Edições Ibama, 2008. 136 p.

STEPP, M. A. Corneal integrins and their functions. Experimental Eye Research, v. 83, n. 1, p. 3-15, 2006. doi: 10.1016/j.exer.2006.01.010.

ZUCCA, P. Anatomy. In: JOHN, E. COOPER. Birds of prey: health \& disease. 3. ed. Osney Mead: Blackwell Science, 2002. p. 13-27. 